\title{
Apresentação
}

\section{Democracia e novas formas de participação política}

Ao longo do século XX, a democracia tornou-se hegemônica no mundo ocidental. Não apenas a democracia como método para a escolha de governantes, mas sobretudo a democracia por seu valor intrínseco, pelo conjunto de valores a ela associados, estando a liberdade e a igualdade entre os mais evidentes.

Isso significa dizer que a democracia transcendeu seu significado original, uma das formas possíveis de governo, para tornar-se um valor em si: para que um governo seja bom, tem que ser democrático. Tornou-se um “dever ser" universal. Questionar a autoridade e, por conseguinte, a legitimidade do povo para orientar a vontade do governo passou a ser inaceitável. Tal universalidade, entretanto, não gerou um consenso quanto aos mecanismos mais eficazes para a consecução dos objetivos democráticos.

A representação política foi consagrada, a partir do século XIX, como método de governo mais adequado a aproximar o exercício governamental da vontade coletiva. Seus princípios visam regular as relações entre representantes e representados, além de definir os mecanismos decisórios, tanto da constituição da representação quanto do exercício da mesma.

n. 2

jul.-dez. 2004

p. $205-209$ 
Diferente do mecanismo de intermediação política, operado pela estrutura representativa do Estado, a participação direta dos cidadãos nos negócios públicos relegou-se à condição de mecanismo complementar, acessado apenas em situações críticas. Apenas a participação eleitoral é regular; outros instrumentos da democracia direta - como o plebiscito, o referendo ou o mandato de injunção - são considerados excepcionais.

Desde a década de 1970, entretanto, a literatura acadêmica vem se ocupando em diagnosticar e encontrar soluções para o que ficou conhecido como a crise da representação política, ou ainda, da própria democracia representativa. Elites políticas encasteladas, apatia política dos cidadãos em geral, ausência de accountability são algumas das evidências apontadas como sendo características da disfunção do mecanismo representativo da democracia.

A partir deste diagnóstico, a mobilização popular em prol da ação política passou a ser valorada positivamente. A fim de resgatar a legitimidade dos sistemas políticos democráticos, novas formas de canalizar a participação política para intervir nas decisões estatais foram desenvolvidas, assim como se ampliaram as esferas de controle social sobre o Estado. Esse processo de mudança originou-se em duas fontes distintas e complementares: se, por um lado, ampliou-se a demanda dos movimentos sociais por maior participação nas decisões estatais, por outro, o próprio Estado tornou-se mais permeável, criando canais, institucionalizados ou não, para a intervenção direta de setores articulados da sociedade.

Inúmeras áreas das ciências humanas - entre elas, a sociologia, a ciência política, a educação e o serviço social - vêm se dedicando a investigar as novas formas de participação política nas democracias contemporâneas. Cabe ressaltar, entretanto, que a amplitude do debate acerca deste tema não se restringe ao campo acadêmico: a sociedade civil organizada tem promovido e participado intensamente de discussões nesse sentido. A agenda do Fórum Social Mundial, cuja quarta edição ocorrerá em janeiro de 2005, em Porto Alegre, revela a importância destas questões para a promoção de uma rearticulação entre Estado e sociedade em parâmetros inovadores. 
Neste número da Revista Civitas, apresentamos discussões teóricas e alguns resultados preliminares de investigações sobre experimentos de democracia direta. Alguns mais otimistas, outros mais céticos quanto à possibilidade de reversão dos desvios da democracia representativa e de seus efeitos sobre as esferas local ou internacional, os artigos que ora se apresentam foram selecionados pela diversidade de perspectivas que abarcam para o tratamento da temática proposta.

O artigo de D’Ávila Filho, Lombardo Jorge e Coelho abre este número contrariando o otimismo daqueles que vêem nos instrumentos participativos da democracia moderna uma possibilidade de romper com um dos aspectos do tradicional círculo vicioso da representação política: o clientelismo político. A possibilidade de perpetuação das trocas assimétricas em processos decisórios que articulam mecanismos de participação aos de representação política inibiria a instauração de um círculo virtuoso capaz de neutralizar as relações clientelísticas entre atores com recursos desiguais de poder. Os autores conduzem uma pesquisa empírica sobre três experiências de Orçamento Participativo no estado do Rio de Janeiro, através da qual buscam sustentar a hipótese de "coextensividade" de trocas políticas assimétricas em dinâmicas decisórias participativas.

O segundo artigo segue explorando a possibilidade de instauração de ciclos virtuosos em sistemas representativos através da ampliação de sua capilaridade, ou seja, da abertura de canais de participação direta na estrutura decisória do Estado. Este texto, de minha própria autoria, tem como objetivo recuperar a discussão teórica acerca do desgaste da democracia representativa, seja pela ausência de accountability estatal, seja pela reprodução continuada de ciclos viciosos em sua dinâmica institucional, explorando os limites e possibilidades de reversão deste quadro. Na última parte deste artigo, proponho uma avaliação quanto à possibilidade de o Orçamento Participativo constituir-se em paradigma da solução virtuosa prevista na discussão teórica. A experiência de Orçamento Participativo investigada foi a do município de Porto Alegre (RS), a mais duradoura e bem-sucedida de que se tem notícia. Seus limites, entretanto, ficam claros ao final do artigo.

Uma análise teórico-conceitual da democracia e seus instrumentos, a participação e a deliberação, é o foco do artigo de Alfredo Gugliano. O 
autor analisa os limites da democracia política, ou formal, uma vez que o funcionamento de um método democrático de seleção de governantes não apenas não implica na existência das democracias social e econômica, como a fragilidade dessas últimas compromete a validade da primeira. No marco da crítica à exclusividade da democracia formal, Gugliano reúne alguns aspectos de contribuições recentes à teoria democrática que apontam para a incorporação de procedimentos deliberativos como instrumentos para a construção de um modelo social de democracia. Nesse sentido, conclui o autor, uma crítica à democracia atual, não se afasta de uma crítica ao próprio capitalismo como modelo socioeconômico desejável.

No plano internacional, os movimentos transnacionais de contestação aos processos de globalização econômica são objeto do artigo de Carlos Arturi. $\mathrm{O}$ autor analisa como a emergência de atores não-governamentais, que organizam protestos e grandes manifestações anti-globalização, geraram respostas dos Estados no sentido de vigiar, controlar e reprimir tais movimentos, intensificando a cooperação policial e de inteligência intergovernamentais. O âmbito da análise de Arturi restringe-se à União Européia, mas já lhe permite considerar o risco potencial às liberdades civis que o surgimento de estruturas de cooperação policial supraestatal representa. Do resultado desses conflitos na esfera política internacional dependeria, segundo o autor, a possibilidade de emergência de uma ordem mundial mais pacífica e democrática.

Também no âmbito da União Européia, o artigo de David Redoli Morchón investiga a participação política dos jovens na atualidade. A relevância especial que o autor confere à juventude como ator político justifica-se pelo fato de que os jovens de hoje serão os protagonistas de um novo modelo de sociedade que se antecipa. Redoli Morchón enfatiza o papel das instituições públicas em promover uma maior integração das gerações mais jovens à esfera pública, criando desenhos institucionais que favoreçam sua atuação política autônoma. Nesse sentido, ao longo do artigo, o autor avalia a eficácia de cinco programas, criados pela Comissão Européia, para a juventude. Além disso, Redoli Morchón considera os serviços prestados pelo Fórum Europeu da Juventude, uma associação voltada à organização juvenil internacional. Suas conclusões apontam para um diagnóstico otimista do movimento associativo juvenil na Europa, registrando a importância do apoio das instituições públicas européias no seu fortalecimento. 
Uma outra dimensão explorada neste conjunto de artigos, a do alcance das políticas sociais e seus efeitos sobre a legitimidade política e a governabilidade, é encontrada no artigo de Paulo J. Krischke. O autor fundamenta-se na discussão sobre os desafios das políticas de redistribuição e reconhecimento para analisar as políticas públicas que têm sido implementadas pelo governo Lula, retomando experiências de democratização da esfera pública implementadas pelo Partido dos Trabalhadores (PT) em âmbito local. O autor também analisa dados de uma pesquisa sobre cultura política da juventude brasileira, traçando um panorama também otimista quanto à identidade política dos jovens neste país.

Finalmente, o artigo de Magdalena Chiara aborda as políticas sociais orientadas para o desenvolvimento local. A autora discute o papel dos novos atores sociais que atuam na promoção de programas descentralizados de desenvolvimento local na Argentina, destacando o potencial democratizante desses processos e os limites até agora enfrentados.

No marco da realização do quarto Fórum Social Mundial, esperamos que os artigos aqui dispostos contribuam para o enriquecimento das discussões que atualmente são travadas, tanto em âmbito acadêmico quanto na esfera pública. Apesar da ampla diversidade de abordagens, os artigos apresentados correspondem à unidade temática proposta neste volume da Civitas, e nos permitem perceber alguns dos limites contidos na ampliação da participação política na esfera pública de decisões e suas contribuições para a superação das fronteiras da democracia representativa.

Marcia Ribeiro Dias 